\title{
Research on the Impact of New Accounting Standards on the Correlation between Capital Market and Investment Efficiency
}

\author{
Zheng Qiu, Zhong Ma, Jia Xu \\ School of Economics and Management, Beijing Jiaotong University, Beijing, China
}

Keywords: ASBE, listed company, statement performance, relevance

\begin{abstract}
The implementation of New ASBE (Accounting Standards for Business Enterprises) has important significance to enhance the transparency of accounting industry in our country and enhance the international competitiveness of capital market of our country. This paper starts from analyzing the basic framework and feature of new ASBE, combined with the actual cases, to explore the important influence of new ASBE on enterprise operation, and puts forward corresponding suggestions on better implementing the new ASBE.
\end{abstract}

\section{Introduction}

The Ministry of Finance of the People s Republic of China published new ASBE on February 15 of 2006, and stipulated to implement it in capital market from January 1 of 2007. The publishing and implementation of new ASBE is another milestone in the accounting history of our country. New ASBE contains one basic standard and 38 specific standards, almost covers all economic businesses of all current enterprises with wide influence and strong standardization, which realizes the substantive convergence with the International Financial Reporting Standards, further unifies the accounting standards, and enhance the operability and intelligibility of accounting standards.

In order to develop rapidly and adapt to the demands of global competition, the listed company should establish a set of standard and scientific accounting standards, the implementation of new ASBE can not only enhance the vitality and attraction of corporate capital market but also give play to the function of capital marketization optimization and configuration, which has important significance to the development of listed company and perfect the capital market in our country.

\section{Feature of New ASBE}

(1) Converge to International Accounting Standards. New ASBE is similar to International Accounting Standards in accounting treatment method. For example, the gains from debt restructuring are transformed from being included in capital reserve to being included in the current profit and loss, and accounting treatment relies on income tax based on international conventions, which will change the taxes payable method adopted by many enterprises previously, besides, new ASBE stipulates to adopt deferred income taxes treatment method, introduces financial instruments accounting standard and firstly introduces the classification and measurement methods consistent with international standards.

(2) It stresses reliability and relevance more for accounting information quality. New ASBE introduces the concept of fair value. The fair value measurement requires to measure the corporate merger, financial instruments and payment based on stock right based on fair value, while for investment-based real estates, the fair value measurement requires to measure the debt reconstructing and non-currency trade based on fair value and include the gains into profit statement when "taking the book value as the measurement standard and determining no gains" is changed as conforming to certain situation.

(3) Establish its own system with wide influence. The new ASBE almost covers all economic businesses of all enterprises, establishes its own system with wide influence, features with strong standardization and can be implemented independently. It parallels with the enterprise accounting system of our country, supplements mutually and perfects the accounting system of our country, 
besides, the development of accounting standards can synchronize with economic environment automatically thus to provide operable standardization and guidance for accounting behavior and enhancing accounting information quality.

\section{Analysis on the New ASBE Affecting the Profit Change of Capital Market}

\subsection{Influence of fair value on the profit of capital market}

Fair value refers to the asset exchange or debt settlement amount familiar to the trade parties in fair trades, which usually reflects the current value of asset or debt. Popularly, under the fair value measurement, the trade parties measure the asset trade or debt settlement in accordance with the market price. The accounting subject "Profit and Loss from Fair Value Changes" used for reflecting the current asset value in the new ASBE makes the profit status of enterprises reflected, which constitutes the enterprise operating profit together with "income from investment". Compared with the original standards, it expands the calculation scope of final profit and enlarges the fluctuation of future profit. What's more, though the fair value measurement changes the calculation method of related businesses, in view of "income from investment", the change has little correlation with the fair value application. Because the new confirmation principle of "income from investment" is consistent with the original one, namely, when disposing of the investment, cash flow and net asset, the Profit and Loss from Fair Value Changes will be included in income from investment.

\subsection{Influence of asset depreciation preparation restitution limitation on the profit of capital market}

(1) Evolution of asset depreciation system

The idea of asset depreciation sources from the conservatism principle. It can be traced back to Italy in the Renaissance Period, Lucar. Pacioli put forward the idea of avoiding overestimating inventory in his mathematics works, which is the first application of "principle of lower of cost or market” and the plain reflection of conservatism principle. Since the 1990s, assets depreciation accounting has entered the stage of comprehensive stage. In face of the increasingly complex and volatile enterprise economic environment and financial crisis, in order to reveal and release the asset depreciation risks, FASB began to research and formulate the long-term asset depreciation and related standards, and started the revision lasting for 20 years. UKASB also began to promote the related asset depreciation accounting. Similar to asset depreciation accounting of America and Britain, IASC also experienced the constant perfectness process of asset depreciation standards, and conducted related promotion as well, meanwhile, our country also conducted related promotion from 1992 to 2006, the current Standard is just the "new ASBE" launched in 2006.

(2) Influence of new asset depreciation standard on the profit of capital market

The key for withdrawing of asset depreciation preparation is to determine the expected economic profit in the future. However, there exists with two problems in reasonably determining the recoverable amount of asset. Firstly, the fair value of asset is difficult to be determined; secondly, the asset group or asset group combination is difficult to be determined; thirdly,goodwill impairment test is difficult to be conducted. Meanwhile, the calculation for asset depreciation measurement is very complicated. The influence of all the above problems on the profit of capital market is non-negligible, and even they may cause the investors lose confidence in enterprise investment, or the market has no patience on enterprises, which finally causes capital chain to be broken thus to cause enterprise bankruptcy.

\section{Statement Performance Situation of Capital Market in Our Country}

The current management situation of capital market in our country mainly can be summarized to be the following aspects:

Firstly, pay attention to microcosmic interests but neglect macroscopic interests. Owing to the enterprise characteristic, enterprises tend to have devotion in benefit pursuing, such as staff salary, welfare and bonus, and give no consideration on national interest, such as purchasing on credit for 
sales expenses, concealment of income and writing false value-added invoices.

Secondly, focus on immediate interests but neglect long-term interests. In view of material purchasing on credit, the operators of capital market tend to consider more about immediate interests, obtain loans from financial institutions and buy materials from suppliers on credit, refuse to behave based on contract, as a result, they can not repay the loan within expiration and pay the material expense in time. Finally, the financial institutions no only lead loans to them and the suppliers allow no purchasing on credit, which causes them to face more intense capital and difficult production, and their long-term benefits can not be guaranteed.

Thirdly, borrow heavy loans but neglect debt settlement. Many operators of capital market tend to rely too much on trading on equity but neglect the risks from large debt scale, if the economy is sluggish and the capital is behind the requirement, the interest rate may increase, at this moment, the debt cost of enterprises will increase, when their earned profit can not compensate for debt interest, enterprises will face a money-losing business and have no capability to repay the loan, which may cause them to be bankrupt under serious situation. Fourthly, focus on value management but neglect site management. The operators of capital market mostly pay more attention to value management and just know the enterprise income, cost and profit, but know little about raw material inventory, supporting degree between spare and accessory parts and the semi-finished products as well as the workshop environment. And even some enterprises have no specialized warehouse but stock the materials and products everywhere, have no strict warehouse input-output procedure, which causes serious waste

\section{Conclusion}

Meanwhile, in face of the implementation of new ASBE, the capital market should firstly accept it mentally, only when they accept it can they absorb and understand it better. The managers of capital market should firstly update the idea of statement performance and establish the objective of statement performance realizing enterprise value maximization. Strengthen the training on financial personnel, including professional ethics training and professional knowledge training. At the same time, the capital market should pay attention to talent introduction and cultivation, establish the incentive, supervision and evaluation mechanism, and increase the sense of belonging of staff. Furthermore, the new ASBE requires the enterprises to strengthen self-control and establish the system of modern enterprise statement performance. The author thinks the capital market should establish the statement performance system suitable to the enterprise feature in accordance with the requirement of "clear capital ownership, clear financial relationship and conformable governance structure of legal person"; at the same time, strengthen the internal control and incorporate the statement performance systems into the standardized route by aid of the accounting information system, budget system and post supervision adjustment system.

\section{References}

[1] Hanpuwadal N, Ussahawanitchakit P. Accounting practice effectiveness and financial performance of Thai listed firms: mediating effects of decision making efficiency for tax management, competent resource allocation, and strategic planning success $[\mathrm{J}]$. International academy of business and economics, 2010, 10(:1).

[2] Azim M. Corporate Governance Mechanisms and Their Impact on Company Performance: A Structural Equation Model Analysis [J]. Social Science Electronic Publishing, 2012, 37(3):481-505.

[3] W.H. Tsai, ShihJieh Hung. A fuzzy goal programming approach for green supply chain optimisation under activity-based costing and performance evaluation with a value-chain structure [J]. International Journal of Production Research, 2009, 47(18):4991-5017.

[4] Uwuigbe U, Uwuigbe O R, Bernard O. Assessment of the Effects of Firms Characteristics on Earnings Management of Listed Firms in Nigeria [J]. Asian Economic \& Financial Review, 2015, 5(2):218-228.

[5] Brentani U D, Kleinschmidt E J. The Impact of Company Resources and Capabilities on Global New Product Program Performance [J]. Project Management Journal, 2015, 46(1):12-29. 